\title{
Antitumoral effects of Amblyomma sculptum Berlese saliva in neuroblastoma cell lines involve cytoskeletal deconstruction and cell cycle arrest
}

\author{
Efeito antitumoral da saliva do carrapato Amblyomma sculptum Berlese em células de neuroblastoma \\ envolve desconstrução do citoesqueleto e parada do ciclo celular \\ Thatyanne Gradowski do Nascimento ${ }^{1}$; Priscilla Santos Vieira ${ }^{2}$; Sheron Campos Cogo'; \\ Marcela Ferreira Dias-Netipanyj ${ }^{1}$; Nilton de França Junior ${ }^{1}$; Diana Aparecida Dias Câmara ${ }^{3}$; Allan Saj Porcacchia ${ }^{3}$; \\ Ronaldo Zucatelli Mendonça ${ }^{4}$; Andréa Novais Moreno-Amaral ${ }^{1}$; Paulo Luiz de Sá Junior ${ }^{3}$; Simone Michaela Simons ${ }^{4}$; \\ Luciana Zischler²; Selene Elifio-Esposito ${ }^{1 *}$ \\ ${ }^{1}$ Programa de Ciências da Saúde, Pontifícia Universidade Católica do Paraná - PUCPR, Curitiba, PR, Brasil \\ ${ }^{2}$ Escola de Ciências da Vida, Pontifícia Universidade Católica do Paraná - PUCPR, Curitiba, PR, Brasil \\ ${ }^{3}$ Laboratório de Genética, Instituto Butantan, São Paulo, SP, Brasil \\ ${ }^{4}$ Laboratório de Parasitologia, Instituto Butantan, São Paulo, SP, Brasil
}

Received October 30, 2018

Accepted December 18, 2018

\begin{abstract}
The antitumor properties of ticks salivary gland extracts or recombinant proteins have been reported recently, but little is known about the antitumor properties of the secreted components of saliva. The goal of this study was to investigate the in vitro effect of the saliva of the hard tick Amblyomma sculptum on neuroblastoma cell lines. SK-N-SK, SH-SY5Y, Be(2)-M17, IMR-32, and CHLA-20 cells were susceptible to saliva, with $80 \%$ reduction in their viability compared to untreated controls, as demonstrated by the methylene blue assay. Further investigation using CHLA-20 revealed apoptosis, with approximately $30 \%$ of annexin- $\mathrm{V}$ positive cells, and G0/G1-phase accumulation $(>60 \%)$ after treatment with saliva. Mitochondrial membrane potential $(\Delta \psi \mathrm{m})$ was slightly, but significantly $(p<0.05)$, reduced and the actin cytoskeleton was disarranged, as indicated by fluorescent microscopy. The viability of human fibroblast (HFF-1 cells) used as a non-tumoral control decreased by approximately $40 \%$. However, no alterations in cell cycle progression, morphology, and $\Delta \psi \mathrm{m}$ were observed in these cells. The present work provides new perspectives for the characterization of the molecules present in saliva and their antitumor properties.
\end{abstract}

Keywords: Tick saliva, animal toxin, tumor cell death, pediatric cancer.

\section{Resumo}

As propriedades antitumorais de extratos de glândulas salivares de carrapatos ou proteínas recombinantes foram relatadas recentemente, mas pouco se sabe sobre as propriedades antitumorais dos componentes secretados da saliva. O objetivo deste estudo foi investigar o efeito in vitro da saliva bruta do carrapato duro Amblyomma sculptum sobre as linhagens celulares de neuroblastoma. Células SK-N-SK, SH-SY5Y, Be(2)-M17, IMR-32 e CHLA-20 foram suscetíveis à saliva, com redução de $80 \%$ na sua viabilidade em comparaçáo com controles não tratados, como demonstrado pelo ensaio de Azul de Metileno. Investigaçóes posteriores utilizando CHLA-20 revelaram apoptose, com aproximadamente $30 \%$ de células positivas para anexina-V, e G0/G1 (> 60\%) após tratamento com saliva. O potencial de membrana mitocondrial $(\Delta \psi \mathrm{m})$ foi reduzido significativamente $(\mathrm{p}<0,05)$, e o citoesqueleto de actina foi desestruturado, como indicado pela microscopia de fluorescência. A viabilidade do fibroblasto humano (células HFF-1), usado como controle não tumoral, diminuiu em aproximadamente $40 \%$. No entanto, não foram observadas alterações na progressão do ciclo celular, morfologia e $\Delta \psi \mathrm{m}$ nestas células. O presente trabalho fornece novas perspectivas para a caracterização das moléculas presentes na saliva e suas propriedades antitumorais.

Palavras-chave: Saliva do carrapato, toxina animal, morte celular tumoral, câncer pediátrico. 


\section{Introduction}

Ticks are specialized hematophagous ectoparasites of significant medical and public health importance (RANDOLPH, 2009). During the penetration process of the host skin, ticks succeed in blood feeding by manipulating the host's hemostatic, inflammatory, and immune defense mechanisms, due to numerous active components with pharmacological applications (CABEZAS-CRUZ \& VALDÉS, 2014; RADULOVIC et al., 2014; STIBRANIOVA et al., 2013). As a source of anti-neoplasic compounds, it has been reported that tick saliva constituents can affect cancer cell proliferation (KAZIMIROVA et al., 2006), apoptosis (AKAGI et al., 2012), migration and invasion (POOLE et al., 2013), and tumor growth and angiogenesis (CARNEIRO-LOBO et al., 2009). Specifically, the cytotoxicity of Amblyomma sculptum Berlese crude saliva (CS) has been demonstrated in melanoma, pancreatic adenocarcinoma (SIMONS et al., 2011), and breast cancer cells (SOUSA et al., 2018). Interestingly, no cytotoxicity was observed in human fibroblasts or non-neoplastic mammary gland cell lines.

Neuroblastoma (NB) is the most common extracranial solid pediatric tumor. These tumors, which account for $15 \%$ of pediatric cancer deaths, occur preferentially in young children with a median age at diagnosis of 18 months (KAMIHARA et al., 2017). In the last 30 years, although significant progress has been achieved in the treatment for high-risk NB, the long-term survival for this group of patients remains under $50 \%$, emphasizing the need for more effective treatments (PINTO et al., 2015).

Despite the advances in the transcriptomic and proteomic characterization of tick's salivary proteins, the biological functions of most of these proteins and their potential for therapeutic and biotechnological use remain unknown (FRANCISCHETTI et al., 2010). Therefore, the search for molecules with antitumor potential in the secreted saliva of ticks may reveal new components of high therapeutic value. In the present study, we demonstrated that the CS of $A$. sculptum shows a high in vitro cytotoxic and anti-proliferative effect in NB cells that involves reduction of the mitochondrial membrane potential $(\Delta \psi \mathrm{m})$ and rearrangement of the cytoskeleton.

\section{Material and Methods}

\section{Saliva collection}

To obtain saliva, 125 female and 50 male ticks were fed the blood of domestic rabbits (Oryctolagus cuniculus) without prior tick infestations. Male (10) and female (25) ticks were placed inside a cotton chamber $(10 \mathrm{~cm} \times 15 \mathrm{~cm})$ on the back of the rabbits. Females that reached $1.0 \mathrm{~cm}$ in width and $1.2 \mathrm{~cm}$ in length on the eighth day of feeding were removed by torsion from the rabbits' backs. Salivation was induced using the methodology described by Kaufman (1978) with minor modifications. Briefly, ticks were ventrally attached to a double-sided tape on a wood base, and $5 \mu \mathrm{l}$ to $10 \mu \mathrm{l}$ of a dopamine solution (Sigma-Aldrich, St. Louis, MO, USA; $5 \% \mathrm{w} / \mathrm{v}$ in $0.15 \mathrm{M} \mathrm{NaCl}$ ) were injected into the dorsal region using a micrometric syringe. Saliva was collected for $4 \mathrm{~h}$ at room temperature in microcapillary tubes fastened to the wood base, with one end in contact with the female's hypostome. The collected saliva was immediately frozen on dry ice. Saliva samples were pooled, filtered $(0.22 \mu \mathrm{m})$, aliquoted, frozen on dry ice and ethanol, and kept at $-80{ }^{\circ} \mathrm{C}$ until use. All experiments were carried out using protocols approved by the Ethics Committee for the Use of Animals of the Butantan Institute (CEUA No 1872100317). CS protein concentration was estimated using the Bradford protein assay (BRADFORD, 1976).

\section{Cell culture}

Human NB cells (Be(2)-M17, CHLA-20, IMR-32, SK-N-SH, and SH-SY5Y) and human foreskin fibroblasts (HFF-1) were cultivated in Dulbecco's Modified Eagle Medium (DMEM)/Ham's F-12 medium (LGC Biotechnology, São Paulo, Brazil) supplemented with $10 \%$ heat inactivated fetal bovine serum (FBS), $100 \mathrm{IU} / \mathrm{mL}$ penicillin, and $0.1 \mathrm{mg} / \mathrm{mL}$ streptomycin (all from Gibco, Thermo Fisher Scientific, Waltham, MA, USA). Cells were maintained at $37^{\circ} \mathrm{C}$ in $5 \% \mathrm{CO}_{2}$. CHLA-20 and IMR-32 NB cells were kindly gifted by St. Jude Children's Hospital (Memphis, TN, USA), SK-N-SH, Be(2)-M17, and SH-SY5Y were obtained from the American Type Culture Collection (ATCC, Manassas, VA, USA). HFF-1 was obtained from the Rio de Janeiro Cell Bank, RJ, Brazil.

\section{Viability assay}

Cells were seeded in 96-well plates $\left(1 \times 10^{4}\right.$ cells/well $)$ and incubated with different concentrations of saliva (serial dilution of CS from $20 \mu \mathrm{g}$ protein $/ \mathrm{mL}$ ) for 24,48 , and $72 \mathrm{~h}$. Cells were fixed with methanol and stained with aqueous methylene blue solution $(0.05 \% \mathrm{w} / \mathrm{v})$ for $10 \mathrm{~min}$. Repeated washings were performed to remove any excess stain that could interfere with reading. After drying, $0.1 \mathrm{M} \mathrm{HCl}$ was added, and the plate was read on a VersaMax ${ }^{\text {тм }}$ ELISA Microplate Reader (Molecular Devices, San Jose, CA, USA) at $630 \mathrm{~nm}$ wavelength.

\section{Clonogenic Assay}

Be(2)-M17, CHLA-20, SK-N-SH, SH-SY5Y, and HFF-1 cells were seeded in 24 -well plates $\left(1 \times 10^{5}\right.$ cells/well $)$, and treated with $5.0 \mu \mathrm{g} / \mathrm{mL}, 10.0 \mu \mathrm{g} / \mathrm{mL}$, and $20.0 \mu \mathrm{g} / \mathrm{mL}$ CS for $72 \mathrm{~h}$. Cells $\left(1 \times 10^{2}\right.$ cells/well $)$ were transferred to a 24 -well plate and cultured for 21 days. Cells were then washed, fixed in methanol, and stained with $0.05 \%$ crystal violet solution.

\section{Fluorescence microscopy}

CHLA-20, IMR-32, and HFF-1 cells were seeded on sterile glass cover slips in 24-well plates and treated with $20 \mu \mathrm{g}$ protein $/ \mathrm{mL}$ CS for $48 \mathrm{~h}$. For fluorescence microscopy, cells were fixed with $3.7 \%$ paraformaldehyde and permeabilized by $0.02 \%$ Triton $\mathrm{X}-100$ diluted in phosphate buffered saline (PBS) containing $10 \%$ FBS for $5 \mathrm{~min}$. To stain actin filaments, cells were labeled with phalloidin-FITC (Molecular Probes, Invitrogen, Carlsbad, CA, USA) in a buffer containing $0.01 \%$ Triton X-100 and 
$1 \mathrm{mg} / \mathrm{mL}$ RNase diluted in PBS. For mitochondrial studies, cells were stained with MitoTracker Red for 45 min under growth conditions. Image analysis was performed with a Nikon Eclipse Ni fluorescence microscope (Tokyo, Japan). Post-acquisition image processing was performed using Image J software (version 14.1, National Institutes of Health, Bethesda, MD, USA).

\section{Flow cytometry detection of apoptosis}

CHLA-20 and HFF-1 cells were seeded in 24-well plates $\left(1 \times 10^{5}\right.$ cells/well) following treatment with $20 \mu \mathrm{g}$ protein $/ \mathrm{mL} \mathrm{CS}$ for $72 \mathrm{~h}$, and stained with Annexin-V and 7-AAD (BD Biosciences, San Jose, CA) according to the manufacturer's instructions. Cells were analyzed by flow cytometry using the BD FACSCalibur instrument (BD Biosciences). Data acquisition and analyses were performed using BD Cell Quest Pro or FlowJo. The measurement of caspase-3 activation was performed using the PE Active Caspase-3 Apoptosis Kit (BD Biosciences). Mitochondrial integrity was evaluated using MitoStatus Red (BD Pharmingen, BD Biosciences).

\section{Cell cycle analysis}

CHLA-20 and HFF-1 cells were treated for $48 \mathrm{~h}$ with $20 \mu \mathrm{g}$ protein $/ \mathrm{mL} \mathrm{CS}$, harvested, fixed in cold $70 \%$ ethanol, and stored at $-20{ }^{\circ} \mathrm{C}$. For cell cycle analysis, cells were washed twice in PBS and re-suspended in the same solution, followed by incubation at $37^{\circ} \mathrm{C}$ for $45 \mathrm{~min}$ with $10 \mathrm{mg} / \mathrm{mL}$ RNase and $1 \mathrm{mg} / \mathrm{mL}$ propidium iodide (Sigma-Aldrich, St. Louis, MO, USA). Flow cytometry analysis was performed using a FACSCalibur system. Cellular DNA content at the different cell cycle phases was determined using ModFit LT software (Verity Software House, Topsham, ME, USA).

\section{Statistical analysis}

Statistical analysis was performed using GraphPad Prism software version 7.0 (GraphPad, San Diego, CA, USA). Quantitative data were expressed as mean $\pm S D$, and analyzed by ANOVA, followed by the multiple comparative Dunnett test, or Student $t$-test, when applicable. A significance threshold of $\mathrm{p}<0.05$ was used.

\section{Results}

\section{A. sculptum CS decreased the viability of all NB cell lines}

The concentration of protein in CS was estimated at $104.2 \mu \mathrm{g} / \mathrm{mL}$. For assays CS concentration was determined by the content of protein. Methylene blue assay results showed that all of the NB cell lines tested were susceptible to CS (Figure 1A). For most cell lines, loss in cell viability was time- and dose-dependent. $\mathrm{IC}_{50}$ values (i.e., the CS concentrations that were cytotoxic for $50 \%$ of the cell populations) were calculated using the 72 -h incubation curves (Table 1). This analysis showed a similar CS toxicity in all NB cells
Table 1. Comparison of the effect of CS on cell viability.

\begin{tabular}{ccc}
\hline Cell Line & $\begin{array}{c}\text { Viable cells }^{(\%)^{\mathbf{A}}} \\
\text { Mean } \mathbf{\pm} \text { SEM }\end{array}$ & $\begin{array}{c}\mathbf{I C 5 0}^{\mathbf{B}} \\
\mathbf{\mu g} / \mathbf{m l}\end{array}$ \\
\hline SK-N-SH & $26.4 \pm 8.2$ & 9.2 \\
SH-SY5Y & $17.9 \pm 4.8$ & 5.4 \\
Be(2)-M17 & $11.6 \pm 4.8$ & 6.9 \\
CHLA-20 & $19.1 \pm 4.8$ & 3.0 \\
HFF-1 & $56.5 \pm 13.1$ & 25.6 \\
\hline
\end{tabular}

${ }^{\mathrm{A}}$ Percentage of viable cells determined after incubation of cell lines for $72 \mathrm{~h}$ with $20 \mu \mathrm{g} / \mathrm{mL}$ protein equalized CS; ${ }^{\text {B }}$ IC50 of CS calculated using the $72 \mathrm{~h}$ incubation curves.

tested (from 3.0 to $9.2 \mu \mathrm{g} / \mathrm{mL}$ ), when compared to the fibroblast cell line HFF-1 $(25.7 \mu \mathrm{g} / \mathrm{mL})$.

Tumor cells also exhibited significant morphological changes upon exposure to CS, such as loss of elongated shape, which is characteristic of neuroblasts (as was observed in the untreated cells) (Figure 1B). However, SH-SY5Y cells maintained an elongated shape, but lost cellular aggregation as compared to the untreated control (Figure 1B). Clonogenic assay results, as shown in Figure 1C, indicate that colony formation was reduced with higher concentrations of CS, notably for the Be(2)-M17 cell line. However, except for these cells, NB cells recovered clonogenic capability in the absence of CS.

\section{A. sculptum CS induced cytoskeleton disassembly}

The fluorescence micrographs in Figure 2 illustrate the morphological changes in CHLA-20 and IMR-32 NB cell lines after treatment with $20 \mu \mathrm{g} / \mathrm{mL}$ CS for $48 \mathrm{~h}$, as evidenced by phalloidin staining. Rounding of the cells and loss of cellular interactions were detected, suggesting a deconstructive effect of the treatment on the actin filaments in cells. In addition, MitoTracker staining was significantly reduced in IMR-32 cells after treatment with CS, which indicates a strong reduction in mitochondrial activity. No difference in mitochondrial activity was observed in the CHLA-20 cells. No significant morphologic alterations in the fluorescence pattern of HFF-1 cells were observed after exposure to CS.

\section{A. sculptum CS induced apoptosis and cell cycle arrest in NB cells}

The dot-blot analysis shown in Figure 3B demonstrates that the remaining NB cells shifted towards Q2 (double marked cells) after treatment with $20 \mu \mathrm{g} / \mathrm{mL}$ CS (48 h), which corresponds to $30 \%$ of apoptotic cells (Figure 2C). In fibroblasts, although a high apoptotic index was found in the untreated cells (approximately $15 \%$ ), it did not increase further after CS treatment. The ability of CS to alter the function of mitochondria in CHLA-20 cells was investigated by flow cytometry. Cells treated with CS exhibited a small, but significant, decrease in MitoStatus Red fluorescence intensity, after $24 \mathrm{~h}$ incubation (Figure 3D, shift to G1). Even with a reduced number of cells exposed to CS after 48 and $72 \mathrm{~h}$, the remaining cells did not show reduced mitochondrial activity when 
compared with the untreated cells. Flow cytometric analysis of DNA content confirmed high sensitivity of the NB cell lines in comparison to the fibroblast cells. CS treatment exerted a pro-apoptotic effect (evidenced by the presence of a sub-G0/G1 peak) accompanied by cell cycle arrest at G1 in the CHLA-20 cells (Figure 4). CS treatment did not affect the cell cycle course of the HFF-1 cells.
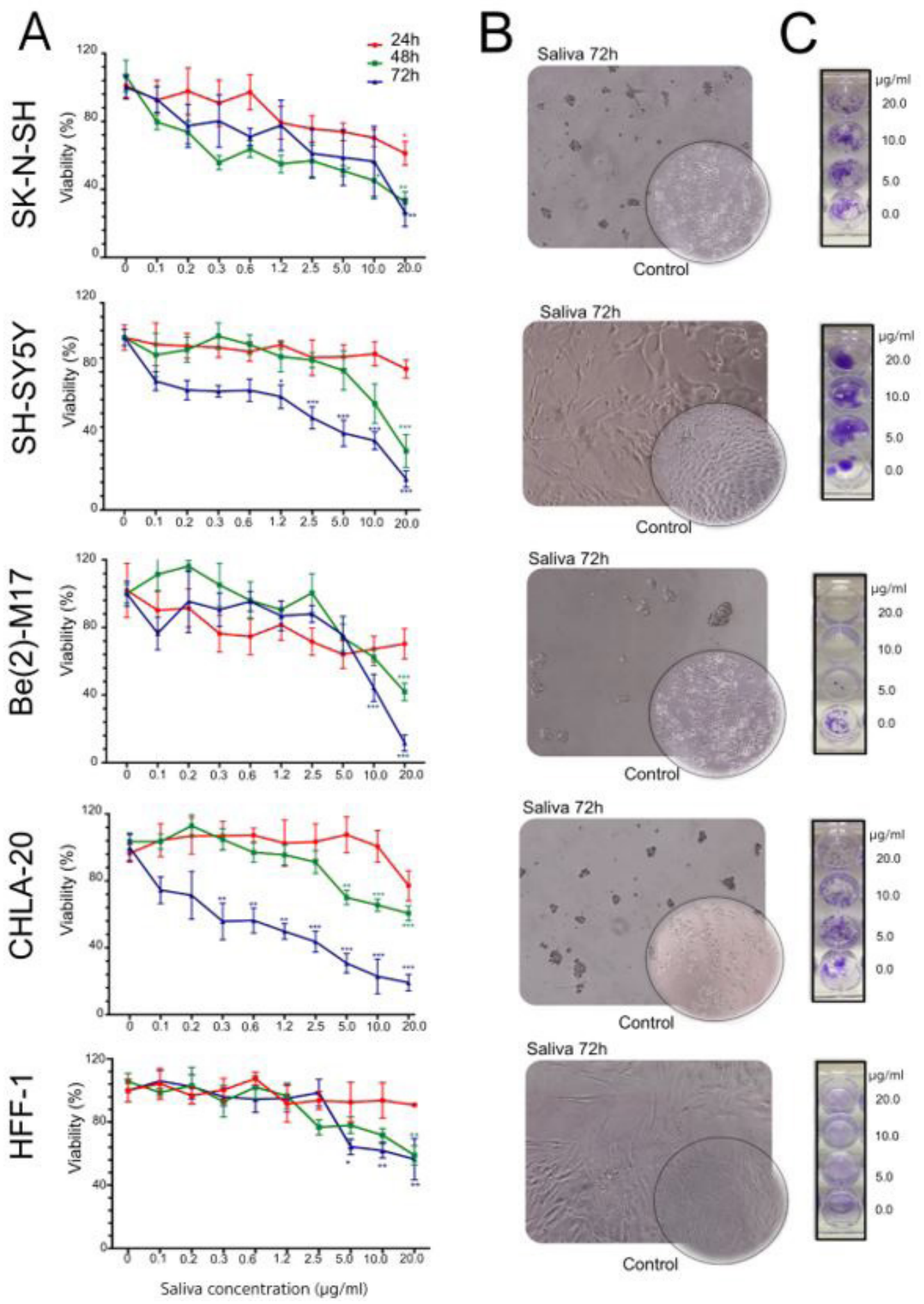

Figure 1. Tick crude saliva (CS) induces cell death in different NB tumor cell lines. NB cells and human foreskin fibroblasts (HFF-1) were treated with $20 \mu \mathrm{g} / \mathrm{mL} \mathrm{CS}$ for $48 \mathrm{~h}$. A) Cell viability was determined by the methylene blue assay performed in three independent tests. Data were analyzed using two-way ANOVA followed by Dunnett's multiple comparison test, in which each group mean was compared with the mean of untreated control. Significant differences are indicated as $\left(^{*}\right) p<0.05,\left({ }^{* *}\right) p<0.01$ and $\left(^{* *}\right) p<0.001$. B) Light microscopy of cell culture after $72 \mathrm{~h}$ incubation with $20 \mu \mathrm{g} / \mathrm{mL}$ CS. C) Representative results of clonogenic assays after independent assays were performed in triplicate. 


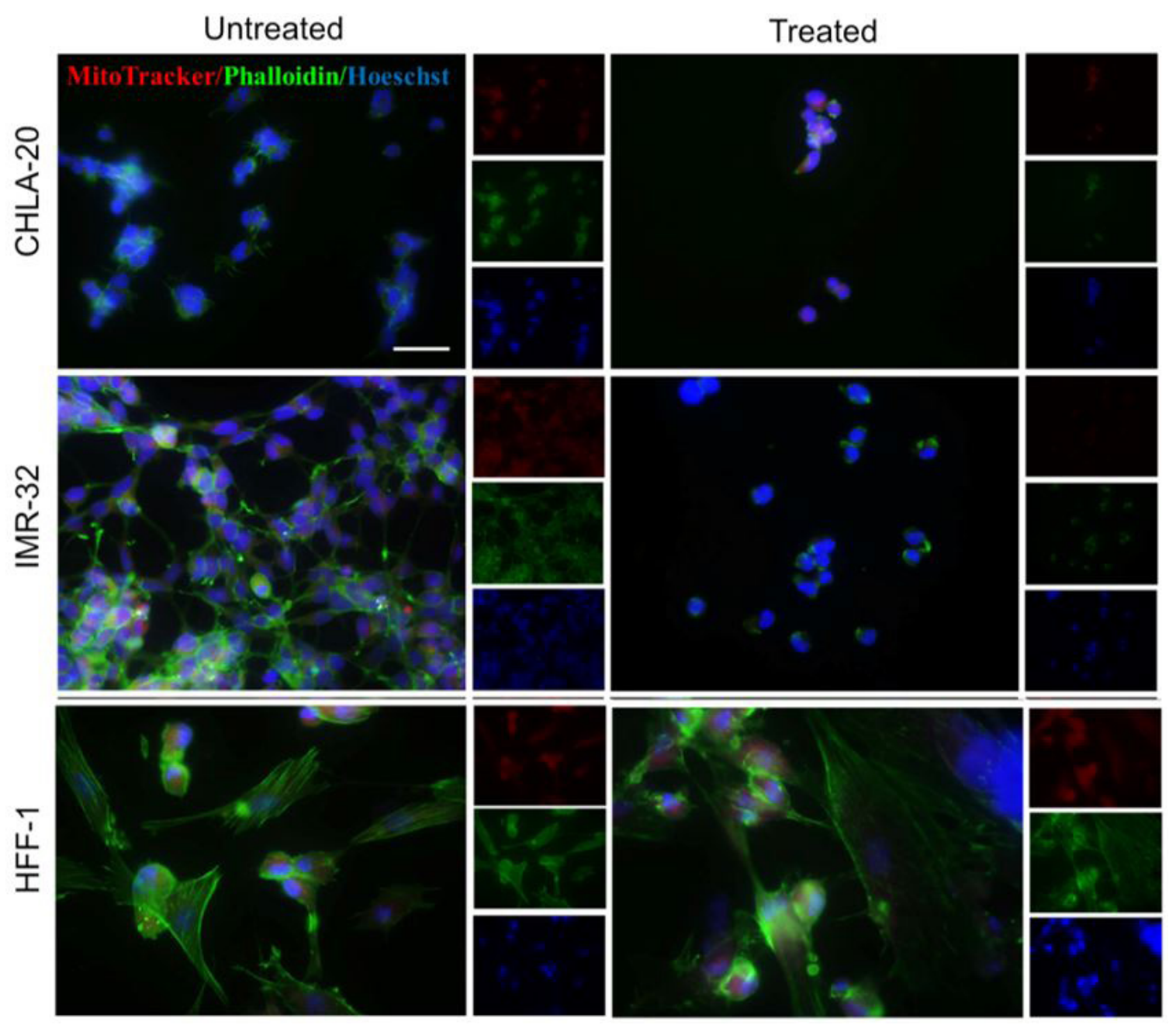

Figure 2. Mitochondria and F-actin disposal detection. Tumor and fibroblast cells were treated for $48 \mathrm{~h}$ with CS and stained with MitoTracker (red), phalloidin-FITC (green) and DAPI (blue). The slides were mounted and observed under fluorescent microscopy at 400× magnification. The experiment was performed in triplicate, and the data shown are representative of each cell line tested.

\section{Discussion}

CS from hematophagous arthropod vectors mediates the successful withdrawal of blood from their hosts by interacting and modifying the functions of a diverse array of cells in the host tissues. In this study, we found that the CS of A. sculptum, (previously cited as Amblyomma cajennense; NAVA et al., 2014), exhibited cytotoxic effects on different human NB cells, supporting the antitumor potential of CS, as reported by Sousa et al. (2015).

Clinical heterogeneity is one of the hallmarks of neuroblastomas (WALTON et al., 2004). NB cell lines can be used as surrogates of NB tumor phenotypes and reveal in vitro their sensitivity to therapeutic compounds. In this study, we initially investigated whether CS could specifically affect undifferentiated NB cells. The SK-N-SH cell line is highly heterogeneous, composed of both of differentiated NB cells (N-type and S-type), and the more tumorigenic undifferentiated I-type cells (BOEVA et al., 2017; ROSS et al., 2015; WALTON et al., 2004). The SH-SY5Y line is a subclone of the SK-N-SH line (THIELE, 1998), and consists of a mixture of the three cell types, along with differentiated N-cells. On the other hand, the Be(2)-M17 and IMR-32 NB cell lines present a fully differentiated phenotypic profile. Our analysis of cell viability showed that all NB cells tested were highly sensitive to CS treatment, with non-significant differences in the IC50, despite their distinct phenotypes.

Cells lines established from patients at diagnosis can be more sensitive to cytotoxic agents than those obtained during disease progression (KESHELAVA et al.,1998). High-risk NB treatment regimens include five to six cycles of induction chemotherapy (PINTO et al., 2015), which for some patients can cause the development of a chemotherapy-refractory disease, suggesting the occurrence of an in vivo selection of drug-resistant tumor cells. The CHLA-20 cell line, predominantly consisting of differentiated cells, was established from a metastatic tumor after chemotherapy with cisplatin, cyclophosphamide, doxorubicin, and teniposide (KESHELAVA et al., 1998), forming a robust model to evaluate the potential of cytotoxic agents, such as CS, on cells that acquired treatment resistance. Here, we showed that CHLA-20 cells were 
A
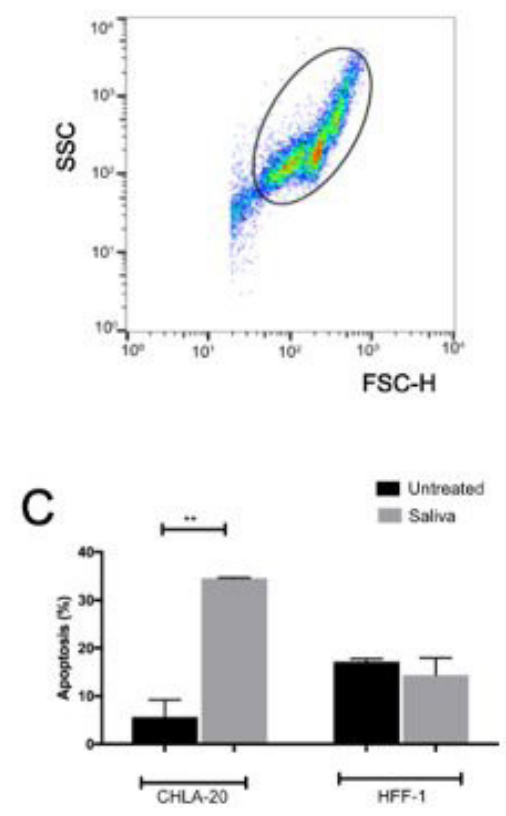

B

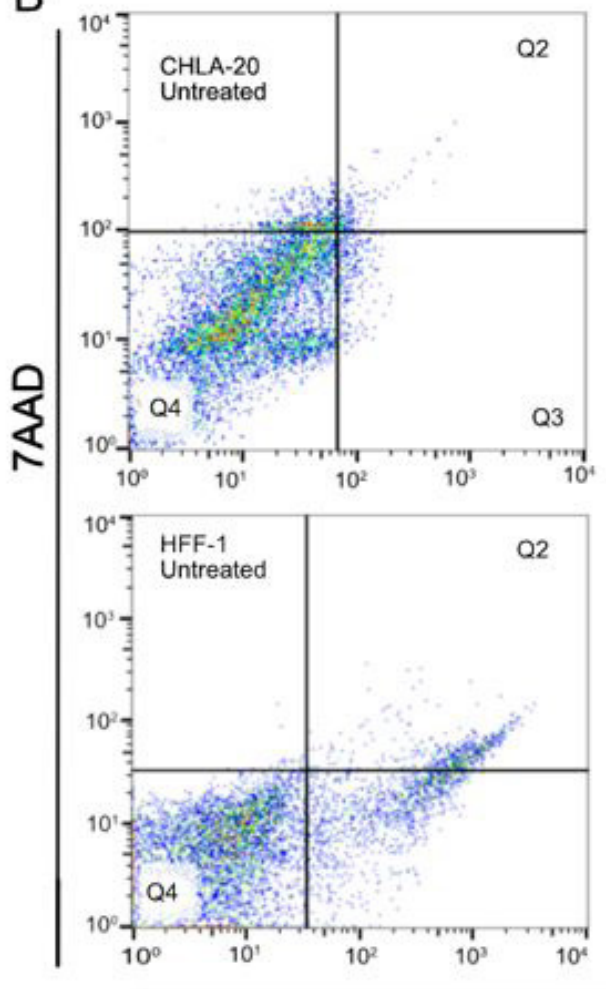

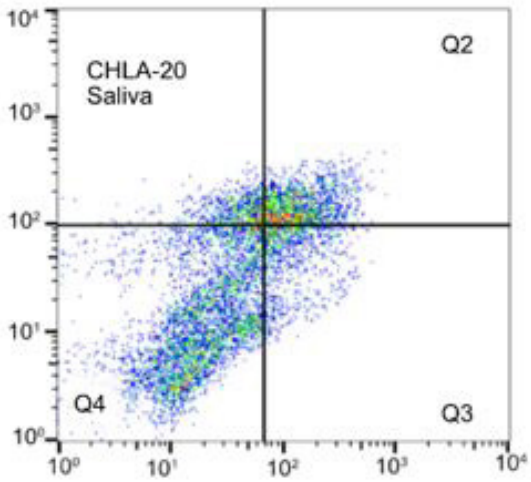

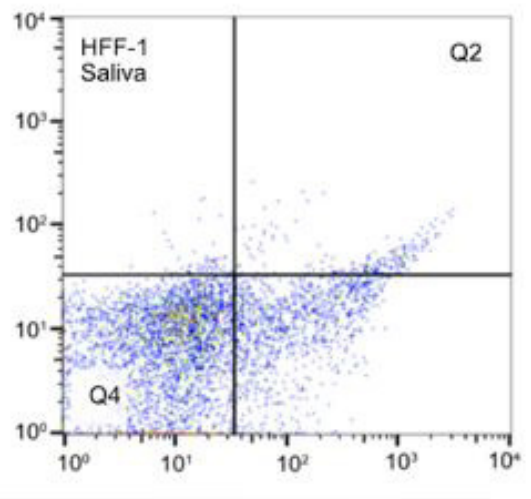

Annexin V

D
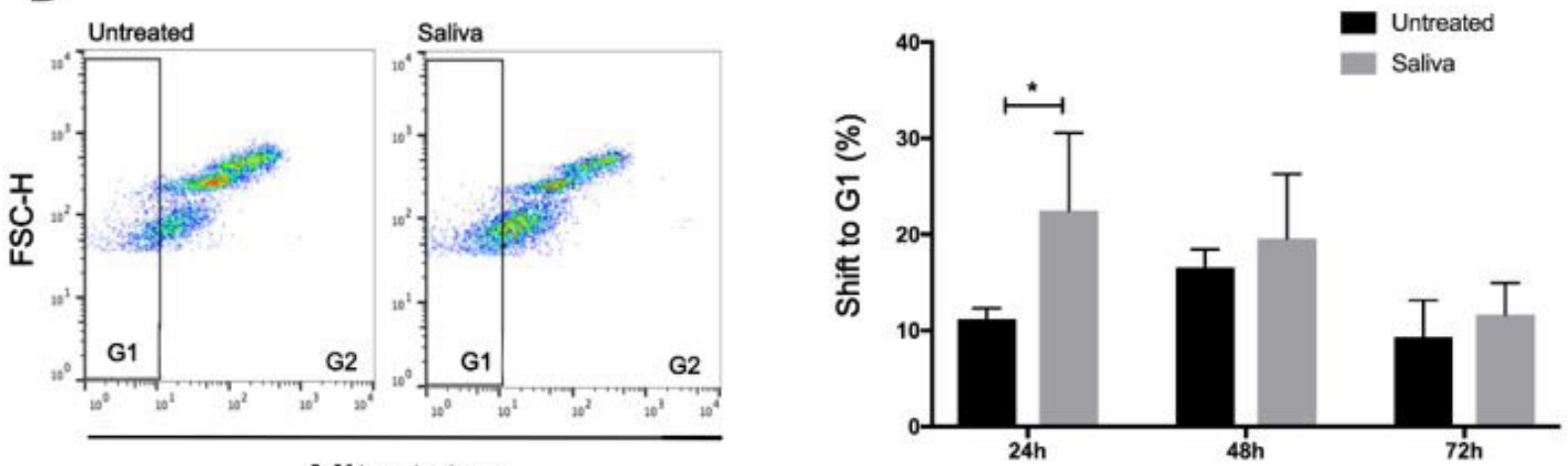

Mltostatus

Figure 3. A. sculptum CS caused apoptosis and disruption of the mitochondrial membrane potential $(\Delta \mathrm{m} \Psi)$ in NB cells. CHLA-20 and HFF-1 cells were treated with $20 \mu \mathrm{g} / \mathrm{mL}$ CS for $72 \mathrm{~h}$ and analyzed by flow cytometry. A) Population of CHLA-20 cells gated and used in the analysis. B) Analysis of apoptosis with Annexin V/7-AAD staining, representative result for CHLA-20 cells. C) Comparative analysis of apoptosis after three independent assays. D) MitoStatus reagent was used to assess mitochondrial membrane potential ( $\Delta \psi \mathrm{m})$ of CHLA-20 cells. While G1 area represents the cell population with depolarized mitochondria, G2 area shows the live cell population with polarized mitochondria. Results are expressed as mean $\pm \mathrm{SD}$, and were analyzed using Student's $t$-test to compare differences between treated group with untreated control. Statistical significances are indicated as $\left(^{*}\right) p<0.05\left(^{* *}\right)$ and $p<0.01$.

very sensitive to $C S$, as demonstrated by the decrease in the percentage of viable cells after 48 and $72 \mathrm{~h}$ incubation, and by the degree of the fractional DNA as a sub G0/G1 population, indicating cell death, as observed in the cell cycle assay.
Additionally, incubation of CHLA-20 cells with CS led to the activation of apoptosis. Approximately $30 \%$ of the treated cells exhibited phosphatidylserine (PS) on the outer layer of the plasma membrane, along with reduction in the mitochondrial membrane 

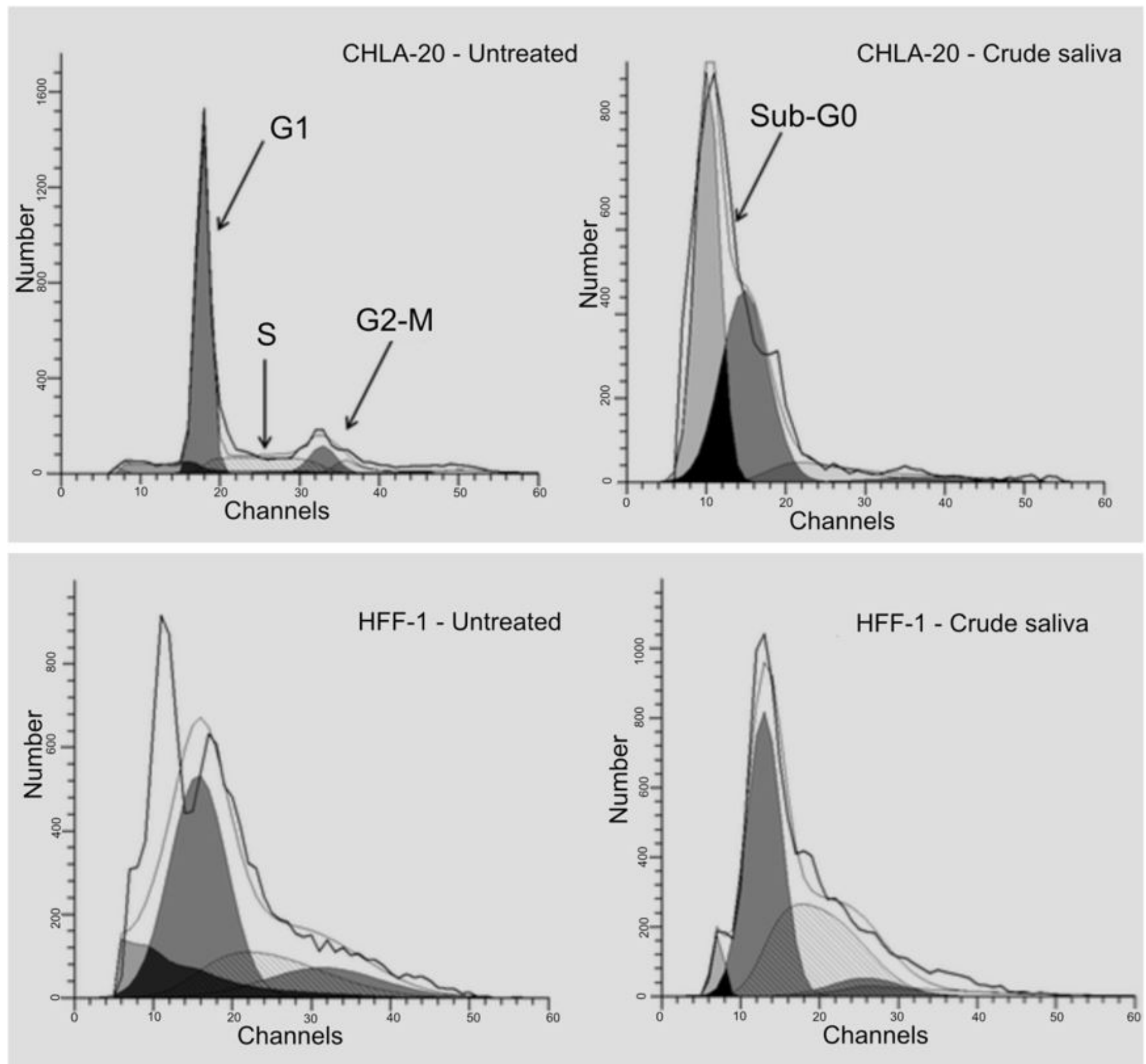

Figure 4. Effects of A. sculptum CS on cell cycle progression. Representative histograms of cell cycle analysis of the CHLA-20 and HFF-1 cells after exposure to CS for $48 \mathrm{~h}$.

potential (at $24 \mathrm{~h}$ incubation), indicating that apoptosis may not be the primary effect of CS on these cells. We further observed that CS did not induce caspase-3 activation (data not shown) in CHLA-20 cells. On the other hand, cytoskeleton disruption was highly apparent in both CHLA-20 and IMR-32 cells, suggesting that detachment of cells, regardless of apoptosis activation, is a determinant for the loss of cell viability and cell death induced by CS treatment.

A previous study demonstrated that the secreted saliva of the hard tick Ixodes scapularis Say was a potent inhibitor of angiogenesis and microvascular endothelial cell proliferation (FRANCISCHETTI et al., 2005). This effect was further accompanied by a change in cell shape (shrinkage of the cytoplasm with loss of cell-cell interactions) and activation of apoptosis, which appeared to be mediated by the endothelial cell $\alpha 5 \beta 1$ integrin. We found similar morphological alterations in NB cell monolayers; however, we did not investigate the involvement of integrins.

The process of cell death triggered by cytotoxic agents is heterogeneous and complex, and although our results indicate that CS cytotoxicity led to apoptotic activation in NB cell lines, other mechanisms of cell death could be involved.

In summary, our study demonstrated that $A$. sculptum CS possesses compounds that affect proliferation and cytoskeleton architecture of NB tumor cells, with no effect on fibroblasts, supporting its therapeutic antitumor potential. Additional in vitro and in vivo analyses are required for the identification and 
isolation of the active molecules from CS that are responsible for the cell phenotype alterations observed in the NB cells in our study.

\section{Acknowledgements}

We thank Dr. Bonald C. Figueiredo from Pelé Pequeno Príncipe Research Institute for the CHLA-20 and IMR-32 neuroblastoma cells kindly gifted. Dr. Luciane R. Cavalli for providing language help and proof reading, and Dr. Lucia de Noronha for comments that greatly improved the manuscript. We wish to express our knowledge for the institutional support of the Butantan Institute and Butantan Foundation for maintenance of the animal facility.

This work was supported by the Coordenação de Aperfeiçoamento de Pessoal de Nível Superior (CAPES-COFECUB 16/2015 \#880/2017, Finance Code 001), Fundação Araucária de Apoio ao Desenvolvimento Científico e Tecnológico do Estado do Paraná - Fundação Araucária (FA 09/2016).

\section{References}

Akagi EM, Sá PL Jr., Simons SM, Bellini MH, Barreto SA, ChudzinskiTavassi AM. Pro-apoptotic effects of Amblyomin-X in murine renal cell carcinoma "in vitro". Biomed Pharmacother 2012; 66(1): 64-69. http:// dx.doi.org/10.1016/j.biopha.2011.11.015. PMid:22281290.

Boeva V, Louis-Brennetot C, Peltier A, Durand S, Pierre-Eugene C, Raynal V, et al. Heterogeneity of neuroblastoma cell identity defined by transcriptional circuitries. Nat Genet 2017; 49(9): 1408-1413. http:// dx.doi.org/10.1038/ng.3921. PMid:28740262.

Bradford MM. A rapid and sensitive method for the quantitation of microgram quantities of protein utilizing the principle of proteindye binding. Anal Biochem 1976; 72(1-2): 248-254. http://dx.doi. org/10.1016/0003-2697(76)90527-3. PMid:942051.

Cabezas-Cruz A, Valdés JJ. Are ticks venomous animals? Front Zool 2014; 11(47): 1-18. http://dx.doi.org/10.1186/1742-9994-11-47. PMid:25006341.

Carneiro-Lobo TC, Konig S, Machado DE, Nasciutti LE, Forni MF, Francischetti IMB, et al. Ixolaris, a tissue factor inhibitor, blocks primary tumor growth and angiogenesis in a glioblastoma model. $J$ Thromb Haemost 2009; 7(11): 1855-1864. http://dx.doi.org/10.1111/j.15387836.2009.03553.x. PMid:19624457.

Francischetti IM, Calvo E, Andersen JF, Pham VM, Favreau AJ, Barbian $\mathrm{KD}$, et al. Insight into the Sialome of the Bed Bug, Cimex lectularius. J Proteome Res 2010; 9(8): 3820-3831. http://dx.doi.org/10.1021/ pr1000169. PMid:20441151.

Francischetti IM, Mather TN, Ribeiro JM. Tick saliva is a potent inhibitor of endothelial cell proliferation and angiogenesis. Thromb Haemost 2005; 94(1): 167-174. PMid:16113800.

Kamihara J, Bourdeaut F, Foulkes WD, Molenaar JJ, Mossé YP, Nakagawara A, et al. Retinoblastoma and neuroblastoma predisposition and surveillance. Clin Cancer Res 2017; 23(13): e98-e106. http://dx.doi. org/10.1158/1078-0432.CCR-17-0652. PMid:28674118.

Kaufman WR. Actions of some transmitters and their antagonists on salivary secretion in a tick. Am J Physiol 1978; 235(1): R76-R81. PMid:677342.

Kazimírová M, Dovinová I, Rolníková T, Tóthová L, Hunáková L. Antiproliferative activity and apoptotic effect of tick salivary gland extracts on human HeLa cells. Neuroendocrinol Lett 2006; 27(Suppl 2): 48-52. PMid:17159778.

Keshelava N, Seeger RC, Groshen S, Reynolds CP. Drug resistance patterns of human neuroblastoma cell lines derived from patients at different phases of therapy. Cancer Res 1998; 58(23): 5396-5405. PMid:9850071.

Nava S, Beati L, Labruna MB, Cáceres AG, Mangold AJ, Guglielmone AA. Reassessment of the taxonomic status of Amblyomma cajennense (Fabricius, 1787) with the description of three new species, Amblyomma tonelliae n. sp., Amblyomma interandinum n. sp. and Amblyomma patinoi n. sp., and reinstatement of Amblyomma mixtum Koch, 1844, and Amblyomma sculptum Berlese, 1888 (Ixodida: Ixodidae). Ticks Tick Borne Dis 2014; 5(3): 252-276. http://dx.doi.org/10.1016/j.ttbdis.2013.11.004. PMid:24556273.

Pinto NR, Applebaum MA, Volchenboum SL, Matthay KK, London WB, Ambros PF, et al. Advances in risk classification and treatment strategies for neuroblastoma. J Clin Oncol 2015; 33(27): 3008-3017. http://dx.doi. org/10.1200/JCO.2014.59.4648. PMid:26304901.

Poole NM, Nyindodo-Ogari L, Kramer C, Coons LB, Cole JA. Effects of tick saliva on the migratory and invasive activity of Saos-2 osteosarcoma and MDA-MB-231 breast cancer cells. Ticks Tick Borne Dis 2013; 4(1-2): 120-127. http://dx.doi.org/10.1016/j.ttbdis.2012.09.003. PMid:23168047.

Radulović ŽM, Kim TK, Porter LM, Sze SH, Lewis L, Mulenga AA. 24-48 h fed Amblyomma americanum tick saliva immuno-proteome. BMC Genomics 2014; 15(518): 1-30. http://dx.doi.org/10.1186/14712164-15-518. PMid:24962723.

Randolph SE. Tick-borne disease systems emerge from the shadows: the beauty lies in molecular detail, the message in epidemiology. Parasitology 2009; 136(12): 1403-1413. http://dx.doi.org/10.1017/ S0031182009005782. PMid:19366480.

Ross RA, Walton JD, Han D, Guo HF, Cheung NK. A distinct gene expression signature characterizes human neuroblastoma cancer stem cells. Stem Cell Res 2015; 15(2): 419-426. http://dx.doi.org/10.1016/j. scr.2015.08.008. PMid:26342562.

Simons SM, Sá PL Jr., Faria F, Batista IF, Barros-Battesti DM, Labruna $\mathrm{MB}$, et al. The action of Amblyomma cajennense tick saliva in compounds of the hemostatic system and cytotoxicity in tumor cell lines. Biomed Pharmacother 2011; 65(6): 443-450. http://dx.doi.org/10.1016/j. biopha.2011.04.030. PMid:21723081.

Sousa ACP, Oliveira CJF, Szabó MPJ, Silva MJB. Anti-neoplastic activity of Amblyomma sculptum, Amblyomma parvum and Rhipicephalus sanguineus tick saliva on breast tumor cell lines. Toxicon 2018; 148: 165-171. http:// dx.doi.org/10.1016/j.toxicon.2018.04.024. PMid:29705147.

Sousa ACP, Szabó MPJ, Oliveira CJF, Silva MJB. Exploring the anti-tumoral effects of tick saliva and derived components. Toxicon 2015; 102: 69-73. http://dx.doi.org/10.1016/j.toxicon.2015.06.001. PMid:26079950.

Stibrániová I, Lahová M, Bartíková P. Immunomodulators in tick saliva and their benefits. Acta Virol 2013; 57(2): 200-216. http://dx.doi. org/10.4149/av_2013_02_200. PMid:23600877.

Thiele CJ. Neuroblastoma cell lines. In: Masters J. Human cell culture. Lancaster: Kluwer Academic Publishers; 1998. (vol. 1) p. 21-53. http:// dx.doi.org/10.1007/0-306-46872-7_2.

Walton JD, Kattan DR, Thomas SK, Spengler BA, Guo HF, Biedler JL, et al. Characteristics of stem cells from human neuroblastoma cell lines and in tumors. Neoplasia 2004; 6(6): 838-845. http://dx.doi. org/10.1593/neo.04310. PMid:15720811. 